\title{
Membrane Properties of Two Types of Basal Cells in Necturus Taste Buds
}

\author{
R. J. Delay, ${ }^{1,2}$ A. Mackay-Sim, ,2,3 and S. D. Roper ${ }^{1,2}$ \\ 'Department of Anatomy and Neurobiology, Colorado State University, Ft. Collins, Colorado 80524, ${ }^{2}$ The Rocky Mountain \\ Taste and Smell Center, University of Colorado Health Sciences Center, Denver, Colorado 80262, and ${ }^{3}$ Faculty of Science \\ and Technology, Griffith University, Nathan, QLD 4111, Australia
}

\begin{abstract}
Necturus taste buds contain two types of basal cells: presumptive stem cells and Merkel-like basal cells. Both types of basal cells are small round cells located at the base of the taste bud, indistinguishable from each other with light microscopy. However, with electron microscopy, autoradiography, or immunocytochemistry, these two types of basal cells can be easily distinguished. We isolated basal cells from taste buds, characterized their voltage-dependent currents using gigaseal whole-cell recordings, and processed the cells for electron microscopy or immunocytochemistry. We were able to distinguish two cell types electrophysiologically and to correlate cell type with membrane properties. Isolated Merkel-like basal cells had several voltage-activated currents: transient, TTX-sensitive, inward $\mathrm{Na}^{+}$current; sustained, saturating outward $\mathrm{K}^{+}$current; and slowly inactivating inward $\mathrm{Ca}^{2+}$ current. These currents are similar to those observed in taste receptor cells. In contrast, presumptive stem cells from Necturus taste buds only had outward $K^{+}$currents.
\end{abstract}

[Key words: Merkel-fike basal cells, presumptive stem cells, 5-HT, voltage-dependent currents, salamander, mudpuppy]

Taste cells are found in clusters, called end organs or taste buds, in the lingual epithelium. There are two major classes of taste cells: elongated cells that extend from the basal lamina to the apical taste pore, and smaller, ovoid basal cells at the base of the taste bud. Many elongated taste cells that reach the pore are electrically excitable (Kashiwayanagi et a1., 1983; Roper, 1983; Avenet and Lindemann, 1987; Kinnamon and Roper, 1987; Sugimoto and Teeter, 1990) and generate action potentials in response to a chemical stimulus (Avenet and Lindemann, 1987, 1991; Kinnamon and Roper, 1988a,b; Behe et al., 1990; Bigiani and Roper, 1991; Gilbertson et al., 1992). The voltage-dependent currents in these taste cells are quite similar to those observed in neurons. For example, in elongated taste cells of $\mathrm{NeC}$ turus, several voltage-dependent currents have been reported: a rapid, transient, tetrodotoxin (TTX)-sensitive inward $\mathrm{Na}^{+}$ current; a noninactivating, outward $\mathrm{K}^{+}$current; and a slowly

\footnotetext{
Received Feb. 10, 1994; accepted Apr. 7, 1994.

We thank Drs. Albertino Bigiani, Douglas Ewald, and Sue Kinnamon for a critical reading of the manuscript and Randy Taylor and Ginger Sammonds for technical assistance. This work was supported by Grants AG06557, DC00374, DC00244, and DC00766.

Correspondence should be addressed to Dr. R. J. Delay, Department of Anatomy and Neurobiology, Colorado State University, Ft. Collins, CO 80523.

Copyright (C) 1994 Society for Neuroscience $0270-6474 / 94 / 146132-12 \$ 05.00 / 0$
}

inactivating $\mathrm{Ca}^{2+}$ current (Kinnamon and Roper, 1988b; Kinnamon et al., 1989; Bigiani and Roper, 1993). Much less is known about the membrane properties of basal taste cells, although Kinnamon and Roper (1988b) reported that presumptive basal cells isolated from Necturus taste buds exhibited voltage-dependent outward current.

Taste buds are in a constant state of cell renewal. Receptor cells are continuously replaced by division and differentiation of basal cells (Beidler and Smallman, 1965; Murray and Murray, 1971; Raderman-Little, 1979; Farbman, 1980; Delay et al., 1986; Oakley, 1991). Presumptive stem cells have been identified in mammalian taste buds and in mudpuppy and turtle (Korte, 1980; Delay et al., 1986; Delay and Roper, 1989). In addition, another class of basal cell has been described in fish, reptiles, and amphibia, termed a Merkel-like basal cell. Merkel-like basal cells have been compared with cutaneous Merkel cells because both cell types share common ultrastructural features such as spines projecting from the cell body and dense-cored vesicles in the cytoplasm. Various roles for Merkel-like basal cells have been proposed. Some investigators have suggested a mechanoreceptive function for the Merkel-like basal cells, by analogy with cutaneous Merkel cells (Hirata, 1966; Jakubowski, 1983). Other researchers have favored the possibility that this cell type releases neurotransmitter(s) and acts as an interneuron within the taste bud (Reutter, 1978, 1986; Delay et al., 1992; Ewald and Roper, 1992; Reutter and Witt, 1993; Roper, 1993). Toyoshima (1994) has suggested that Merkel-like basal cells are the progenitors of developing taste buds and exert a neurotrophic influence over the subsequent development of taste receptor cells.

Recently, Bigiani and Roper (1993), using a semi-intact lingual slice preparation, reported two types of basal cells in mudpuppy taste buds based on differences in their electrophysiological profiles. However, an attempt to correlate electrophysiological differences with cell type was not made in that study. There does not yet appear to be a consensus on the electrophysiological properties or function(s) of basal taste cells. In the present study we used the whole-cell patch-clamp technique, immunocytochemistry, and light and electron microscopy to study the two classes of basal cells isolated from Necturus taste buds. After examination of voltage-dependent currents, recorded cells were identified with electron microscopy (EM) or immunocytochemistry. Presumptive stem cells had only voltage-dependent outward $\mathrm{K}^{+}$currents that were slowly activating. Merkel-like basal cells had several voltage-dependent currents: a TTX-sensitive, rapidly inactivating $\mathrm{Na}^{+}$current; a sustained, 
saturating $\mathrm{K}^{+}$current; and a slowly inactivating, inward $\mathrm{Ca}^{2+}$ current.

\section{Materials and Methods}

Mudpuppies (Necturus maculosus) were obtained from commercial vendors. Animals were kept in $5 \%$ artificial seawater at $8-10^{\circ} \mathrm{C}$. After being anaesthetized with ice water, the animals were killed by decapitation. Lingual tissue was removed from the tongue with blunt dissection. Isolated taste cells were prepared by the method described in Kinnamon et al. (1988). Briefly, the lingual tissue was pinned out in a Sylgardcoated dish, rinsed with amphibian physiological saline (APS) solution [112 mm NaCl, $2 \mathrm{~mm} \mathrm{KCl}, 8 \mathrm{~mm} \mathrm{CaCl}_{2}$, 5 mм HEPES ( $N$-2-hydroxyethylpiperazine- $N$ ' ethanesulfonic acid) buffered to $\mathrm{pH} 7.2$ with $\mathrm{NaOH}$ ] and then treated with a $0.1 \%$ solution of collagenase (Worthington Biochemical Corp.) in APS plus $0.1 \%$ albumin until the surrounding nontaste epithelium could be gently peeled away from the tongue. Under these conditions, taste buds were left behind on their pedestals of connective tissue. After $10 \mathrm{~min}$ in calcium-free APS, individual taste cells could be withdrawn with a fire-polished pipette and gentle suction and placed in plastic petri dishes coated with Cell-Tak (Collaborative Research) for recording.

Electron microscopy. Intact taste buds with the surrounding tissue were fixed with $2 \%$ glutaraldehyde in $0.05 \mathrm{M}$ sodium cacodylate buffer ( $\mathrm{pH} 7.2$ ). After several buffer washes, the tissue was postfixed with $2 \%$ $\mathrm{OsO}_{4}$, and then dehydrated through a graded ethanol series and embedded in Spurr's plastic. Thin sections were cut with a Reichert Ultracut $E$ microtome, placed on Formvar-coated slot grids, and then stained with uranyl acetate and lead stain. Sections were examined and photographed with a JEOL 2000 electron microscope. For isolated taste cells, each cell was fixed following electrophysiological recording, and then photographed with an Olympus IMT2 inverted microscope equipped with Hoffman optics and epifluorescence. A scribe was used on the bottom of the recording dish to encircle the recorded cell to facilitate its location during further processing. Cells that were to be inspected with electron microscopy (EM) were fixed with $2 \%$ glutaraldehyde in $0.05 \mathrm{M}$ sodium cacodylate buffer. Isolated cells were processed as above except they were embedded in Epon Araldite instead of Spurr's plastic. Electron micrographs allowed us to identify Merkel-like basal cells with confidence.

Immunocytochemistry. Merkel-like basal cells also could be identified immunocytochemically by labeling the cells with an antiserum to serotonin (5-HT). Merkel-like basal cells contain 5-HT whereas the other cells in the taste bud do not (Delay et al., 1993b). Isolated cells were fixed in $2 \%$ formaldehyde (freshly made from paraformaldehyde) in $0.05 \mathrm{M}$ sodium cacodylate buffer (pH 7.2) that also contained $0.25 \%$ Triton. The cells were then processed by the method described in Delay et al. (1993b). In brief, cells were exposed to primary antiserum against anti-serotonin-bovine serum albumin (BSA) conjugate (Incstar; 1:1000) for $12 \mathrm{hr}$ at $7^{\circ} \mathrm{C}$. The tissue was washed in phosphate-buffered saline (PBS) for $45 \mathrm{~min}$ at room temperature and then FITC-labeled goat antirabbit IgG secondary antiserum (Cappel; 1:100) was applied to the sections for $2.5 \mathrm{hr}$ at room temperature. Both the primary and secondary antibodies were diluted in PBS containing $0.25 \%$ BSA.

Presumptive basal stem cells. To label stem cells selectively, animals were injected twice with tritiated $\left({ }^{3} \mathrm{H}\right)$ thymidine $(1.5 \mu \mathrm{Ci} / \mathrm{gm}$ body weight; specific activity, $74 \mathrm{Ci} / \mathrm{mol}$ ), $12 \mathrm{hr}$ apart, and killed $12 \mathrm{hr}$ after the second injection. The tissue was treated like the unprocessed taste buds (see above) through the embedment procedure. After embedding in Spurr's plastic, the tissue was serially sectioned at $2.5 \mu \mathrm{m}$ and the sections were placed on gelatin-coated glass microscope slides. The slides were dipped in Kodak MTB2 emulsion and exposed for $8 \mathrm{~d}$. Taste buds with labeled cells were photographed with a Zeiss Axiophot microscope. Selected sections were then removed from the glass slide, glued to blank blocks, and resectioned for EM.

Gigaseal whole-cell recording. Membrane currents were recorded and analyzed using the whole-cell configuration of the patch-clamp technique (Hamill et al., 1981). Electrodes were made from hematocrit capillary tubes and coated with a soft dental wax. The resistance of the pipette was normally between 3 and $6 \mathrm{M} \Omega$ when filled with our standard intracellular solution (below).

Whole-cell currents were measured at room temperature using an Axopatch $1 \mathrm{D}$ patch-clamp amplifier (Axon Instruments). Voltage pulses applied to the pipette were controlled by a computer system (11/73, Digital Equipment Corp.) equipped with a Cheshire data interface (Indec
Systems). Membrane capacitance was estimated by integrating the capacitative transient and dividing by the amplitude of the voltage step. A membrane capacitance of $1 \mu \mathrm{F} / \mathrm{cm}^{2}$ was assumed for the membrane surface area calculations. Pipette resistance and the membrane capacitance were electronically canceled with the patch-clamp amplifier. Leak and linear capacitative currents were measured by a series of hyperpolarizing pulses $(-25 \mathrm{mV})$ applied to the pipette from the holding potential. These currents were automatically subtracted from the records.

Voltage-activated $\mathrm{Na}^{+}$and $\mathrm{K}^{+}$currents were recorded with APS in the bath and a standard intracellular solution (buffered to $\mathrm{pH} 7.2$ with $\mathrm{KOH}$ ) that contained $80 \mathrm{~mm}$ potassium gluconate, $10 \mathrm{~mm} \mathrm{NaCl}, 10$ mM HEPES, $2 \mathrm{~mm} \mathrm{MgCl}, 1 \mathrm{~mm}$ BAPTA (Molecular Probes), $0.09 \mathrm{~mm}$ $\mathrm{CaCl}_{2}, 5 \mathrm{~mm}$ ATP, and $0.5 \mathrm{~mm}$ GTP. To examine $\mathrm{Ca}^{2+}$ currents, the bath contained $94 \mathrm{~mm} \mathrm{NaCl}, 20 \mathrm{~mm} \mathrm{BaCl}, 2 \mathrm{~mm} \mathrm{KCl}, 5 \mathrm{~mm}$ HEPES, $10 \mathrm{mM}$ TEA-Br (tetraethylammonium bromide), and $1 \mu \mathrm{M}$ tetrodotoxin (TTX). The intracellular solution used for measuring $\mathrm{Ca}^{2+}$ currents consisted of $100 \mathrm{~mm}$ cesium acetate, $10 \mathrm{~mm} \mathrm{NaCl}, 10 \mathrm{~mm}$ HEPES, $0.023 \mathrm{~mm} \mathrm{CaCl}_{2}, 0.1 \mathrm{~mm}$ EGTA, $2 \mathrm{~mm} \mathrm{MgCl}_{2}, 5 \mathrm{~mm}$ ATP, and 0.5 mM GTP.

\section{Results}

Vertebrate taste buds are composed of elongated cells oriented longitudinally with respect to the taste bud and small round cells located at the base of the taste bud (Farbman, 1965; Murray, 1973; Kinnamon, 1988; Roper, 1992). In Necturus this latter category, the basal cells, can be further divided into two types: Merkel-like basal cells and undifferentiated cells (Delay and Roper, 1989). Merkel-like basal cells are quite distinctive (Farbman and Yonkers, 1971; Reutter, 1971, 1978, 1986; During and Andres, 1976; Jakubowski, 1983; Delay and Roper, 1988). They have two distinguishing ultrastructural features: small spiny processes extending from the cell body, and numerous dense-cored vesicles within the cytoplasm. Merkel-like basal cells are involved in the majority of the observed synapses in Necturus taste buds (Delay and Roper, 1988). These cells have recently been shown to be the only taste cells in Necturus taste buds to contain serotonin (5-HT; Delay et al., 1993b). In contrast to Merkel-like basal cells, the cytoplasm of undifferentiated basal cells contains numerous polysomes, smooth and rough endoplasmic reticulum, Golgi, many mitochondrial profiles, and abundant tonofilaments (Korte, 1980; Delay and Roper, 1989). The lack of distinguishing features suggests that these basal cells represent an undifferentiated, dividing population (presumptive stem cells), as suggested by others (Lebond and Cheng, 1976; Korte, 1980) and shown experimentally below.

\section{Stem cells: autoradiography and ultrastructure}

In order for regeneration of taste cells there presumably is a selfrenewing stem cell population. However, to date there has been no definitive ultrastructural study identifying stem cells in taste buds. Thus, we have defined any cell that accumulates ${ }^{3} \mathrm{H}$-thymidine within $24 \mathrm{hr}$ after injection as a "presumptive stem cell." Figure $1 a$ shows a light micrograph of an oblique section through a taste bud from an animal killed $12 \mathrm{hr}$ after its second injection of ${ }^{3} \mathrm{H}$-thymidine. A basal cell (arrows) labeled with silver grains can be clearly observed located laterally at the base of the taste bud. This same section was reembedded and sectioned for EM. At low magnification the labeled basal cell was easily recognized (Fig. $1 b$, asterisks) by its position relative to the other taste cells in the bud. Figure $1 c$ shows a higher magnification of a portion of the cytoplasm of the stem cell. Note the presence of mitochondria, several bundles of tonofilaments, and some polysomes. Located directly below the labeled stem cell was an unlabeled Merkel-like basal cell (Fig. 1b). Although the profiles of 
two or three Merkel-like basal cells were normally present in any given section of a taste bud, we never observed ${ }^{3} \mathrm{H}$-thymidinc-labcled Merkel-like basal cells under these conditions (within $24 \mathrm{hr}$ after injection of ${ }^{3} \mathrm{H}$-thymidine). We conclude that Merkel-like basal cells do not represent a dividing cell population.

\section{Presumptive stem cells: electrophysiology}

Cells were isolated from Necturus taste buds and plated onto plastic petri dishes. Small round cells could be distinguished from elongated taste cells and studied with patch electrode recording. Figure $2 a$ shows a light micrograph of an isolated basal cell that had been examined using the whole-cell configuration of the patch-clamp technique. The position of the single cell was marked by a scribe on the bottom of the dish. This mark caused the out-of-focus halo at the periphery of the micrograph. After recording, the cell was fixed and sectioned for EM. This recorded cell is shown in a low-magnification view in Figure $2 b$. Although its ultrastructural features were not ideal, sufficient preservation was achieved to identify this cell confidently as a stem basal cell (Fig. 2b,c). In particular, it lacked features that distinguish Merkel-like basal cells, such as dense-cored vesicles. Moreover, it possessed a cytoplasmic organization (i.e., same types and relative numbers of organelles) similar to that found in stem basal cells from intact taste buds (Fig. 1c).

When held at $-80 \mathrm{mV}$ and pulsed in $10 \mathrm{mV}$ steps from -40 to $+80 \mathrm{mV}$, only outward currents were elicited from the stem basal cell shown in Figure 2 (Fig. $2 d$ ). The outward voltagegated currents were partially blocked by TEA and activated near $0 \mathrm{mV}$, which suggested that these currents were carried by $\mathrm{K}^{+}$ (Kinnamon and Roper, 1988a,b). The outward $\mathrm{K}^{+}$current activated much slower than the $\mathrm{K}^{+}$current in elongate taste receptor cells (Kinnamon and Roper, 1988b) and Merkel-like basal cells (compare Fig. 4c). This cell was not an epithelial cell, since Kinnamon and Roper (1987) had shown that lingual epithelial cells in Necturus do not possess voltage-activated currents. The average membrane capacitance $( \pm \mathrm{SEM})$ of this class of basal cell was $29.4 \pm 1.6 \mathrm{pF}(n=19)$ and none of these cells ( 0 of 19$)$ possessed voltage-activated inward currents $\left(\mathrm{Na}^{+}\right.$or $\mathrm{Ca}^{2+}$ ). The mean peak current density ( \pm SEM) for the outward current, measured at $+80 \mathrm{mV}$ (at the end of the $17.5 \mathrm{msec}$ pulse), was $71 \pm 22 \mathrm{pA} / \mathrm{pF}$.

\section{Merkel-like basal cells: ultrastructure and immunocytochemistry}

Merkel-like basal cells are located in a ring at the periphery of the base of taste buds in Necturus (Delay et al., 1993b; Kim et al., 1993). The cytoplasm of Merkel-like cells contains numerous dense-cored vesicles and these dense-cored vesicles are readily apparent in the cytoplasm of every section of this cell type. Less numerous, but quite distinctive, are the small spines that project from these cells. These two fcatures, spines and dense-cored vesicles, are characteristic of Merkel-like basal cells in Necturus taste buds, as shown in Figure $3 a$. When Merkellike basal cells were isolated from taste buds and fixed shortly after isolation, both of these ultrastructural features were present (Fig. 3b,c). Dense-cored vesicles ranged in size from 80 to 190 $\mathrm{nm}$ (Fig. $3 c$ ). After more than $15 \mathrm{~min}$ in vitro, the spiny projections of Merkel-like basal cells appeared to be reabsorbed. However, even after whole-cell patch-clamp recording, densecored vesicles remained in the cytoplasm of Merkel-like basal cells (Fig. $4 a, b$ ).

Merkel-like basal taste cells could also be identified with immunocytochemical staining for 5-HT (Delay et al., 1993b). We were able to identify Merkel-like basal cells after patch-clamp recording by processing the recorded cell for 5-HT immunostaining. Figure $5 a$ shows two isolated taste cells. These cells were fixed after recording wholc-ccll currents from the smaller cell. Figure $5 b$ is the fluorescence image of these same two cells after 5-HT immunostaining. The smaller of the two cells was immunopositive for 5-HT (thus is a Merkel-like basal cell) while the larger cell was immunonegative for 5-HT.

\section{Merkel-like basal cells: electrophysiology}

Merkel-like basal cells possessed voltage-dependent inward and outward currents. From a holding potential of $-80 \mathrm{mV}$, the Mcrkel-like basal cell shown in Figure 4 was pulsed in $10 \mathrm{mV}$ steps from -40 to $+80 \mathrm{mV}$ (Fig. $4 \mathrm{c}$ ). Inward current activated near $-20 \mathrm{mV}$, and reached a peak at about $0 \mathrm{mV}$. This current was blocked by TTX, indicating that this inward current was a $\mathrm{Na}^{+}$current. Outward current activated near $0 \mathrm{mV}$, increased almost linearly with increased depolarization, and then saturated around 60 to $70 \mathrm{mV}$ (Fig. $4 c, d$ ). The outward current in Merkel-like basal cells activated more rapidly than that in stem

Figure 1. Identification of stem basal cclls in Necturus tastc cclls, using uptake of ${ }^{3} \mathrm{H}$-thymidine as a marker. $a$ is a modulation-contrast light micrograph of a longitudinal section through a taste bud from an animal killed $24 \mathrm{hr}$ after the first injection of ${ }^{3} \mathrm{H}$-thymidine. The arrows point to a stem cell heavily labeled with silver grains. This section was reembedded and sectioned for cell type verification with EM (b). The asterisks mark the cell labeled with silver grains in $a$. Its location is superior to a Merkel-like basal cell $(M)$. A higher-magnification view of the upper portion of the labeled stem cell is shown in $c$. Small bundles of tonofilaments, several mitochondrial profiles, and smooth and rough endoplasmic reticulum are apparent in the cytoplasm of this cell.

Figure 2. Ultrastructural features and voltage-dependent currents of an isolated presumptive stem cell. $a$ is a light micrograph of an isolated basal cell (arrow) after the cell had been fixed following electrophysiological recording. Note the "halo" around the cells caused by the encircling scribe used to mark the recorded cell through the processing. Under the electron microscope, the plasma membrane of this cell appeared very blebby, with large loops of membrane-bound cytoplasm extending from the cell $(b, c)$. Examination of the cytoplasm at a higher magnification $(c)$ reveals the presence of many mitochondrial profiles and swollen ER. The voltage-activated currents of this cell are shown in $d$. Only slowly activating outward $\mathrm{K}^{+}$currents were elicited when the cell was pulsed from -40 to $+80 \mathrm{mV}$ in $10 \mathrm{mV}$ steps from a holding potential of $-80 \mathrm{mV}$.

Figure 3. Ultrastructural features of intact and isolated Merkel-like basal cells. $a$ shows a portion of a Merkel-like basal cell in an intact taste bud. An arrow points to a spine projecting from plasma membrane, and arrowheads point to dense-cored vesicles in the cytoplasm. Spines (arrows) and dense-cored vesicles (arrowheads) are still apparent in an isolated Merkel-like basal cell $(b) . c$ is a higher magnification of a portion of the cytoplasm of the isolated cell in $b$ showing the dense-cored vesicles in greater detail. 

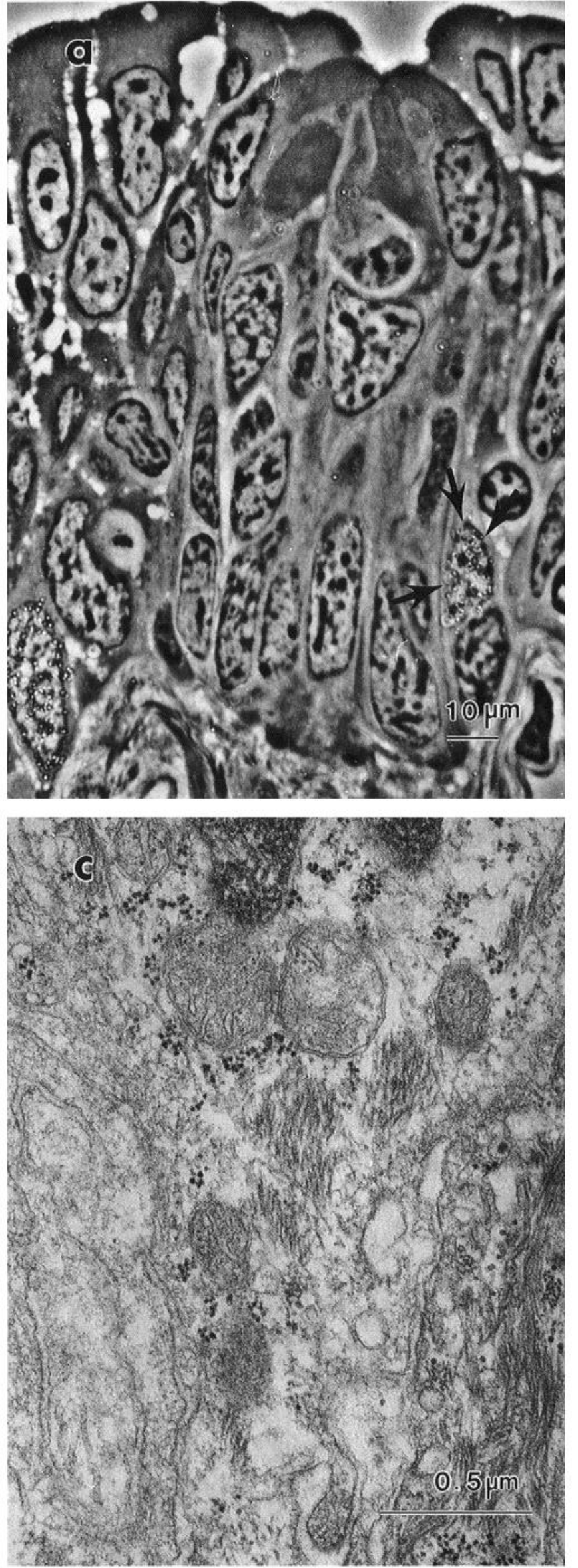

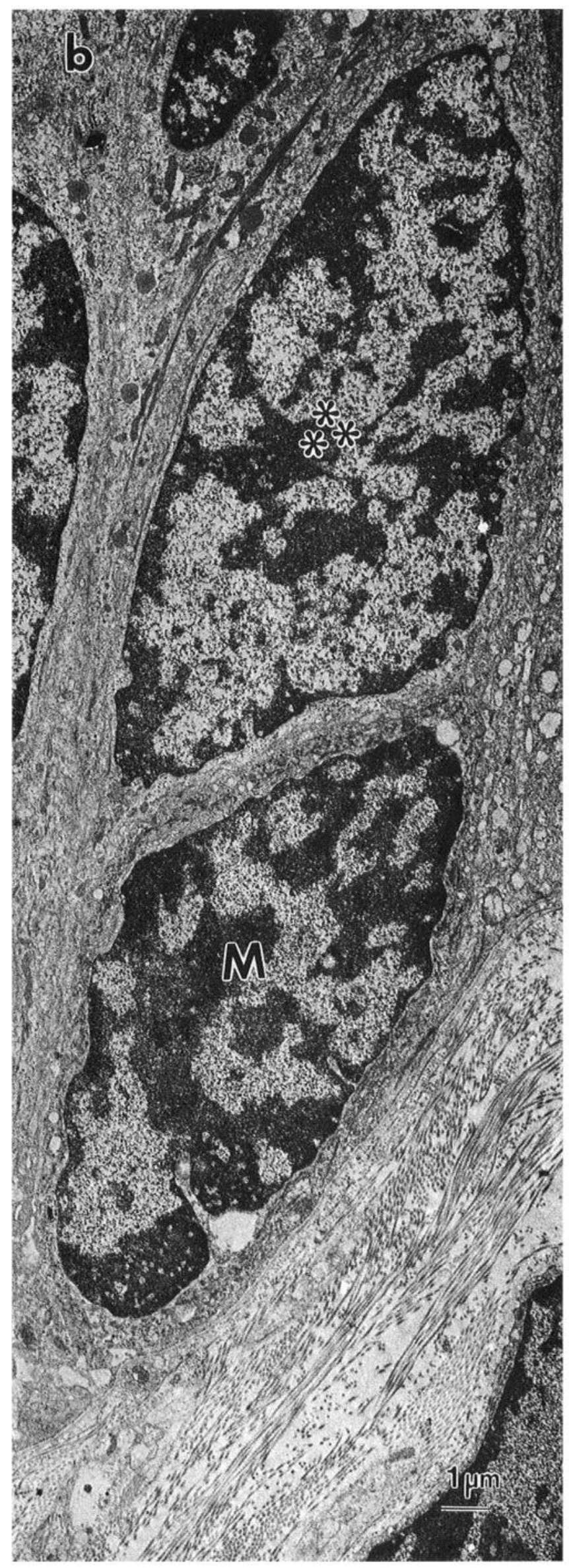



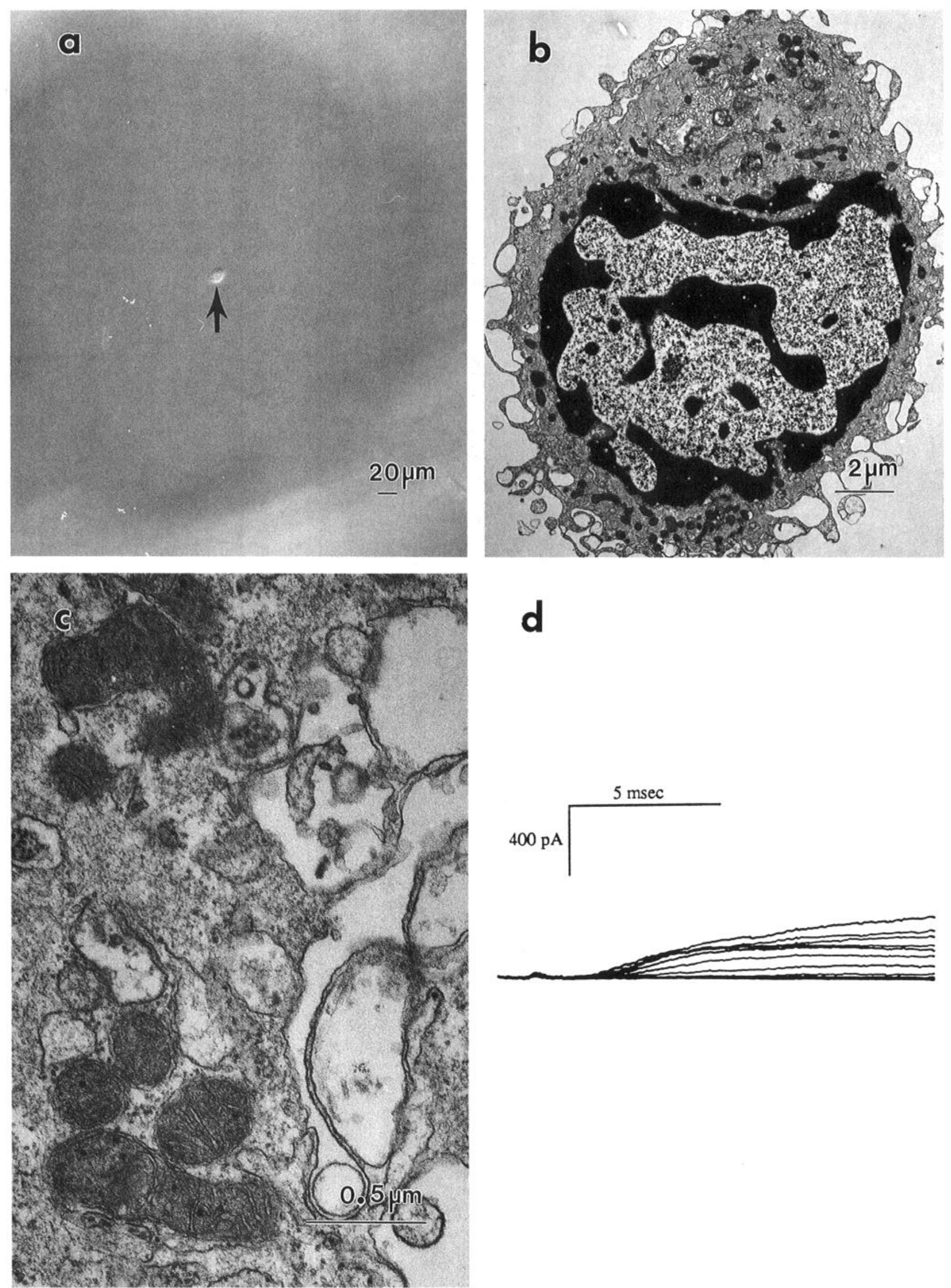

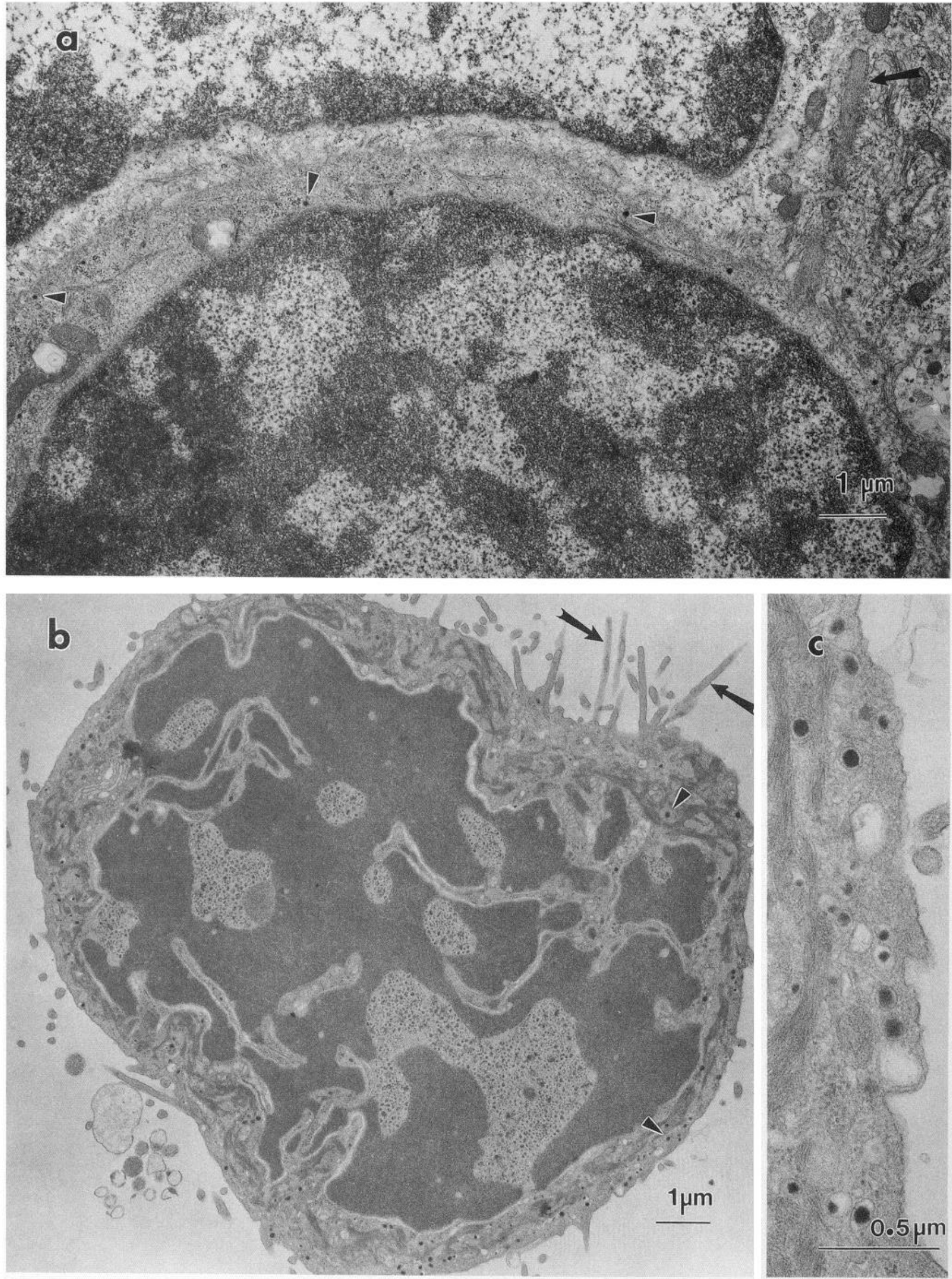

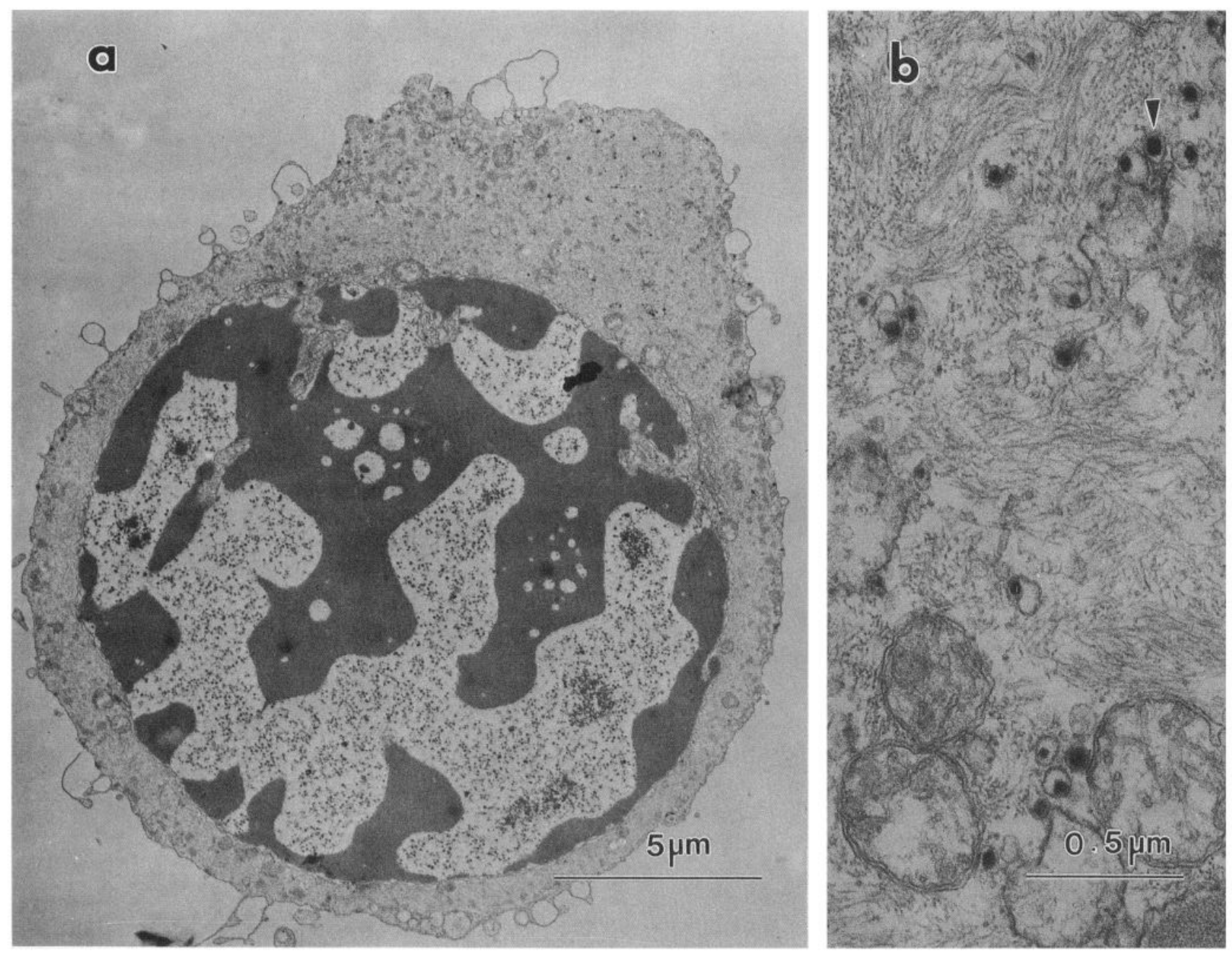

\section{C}

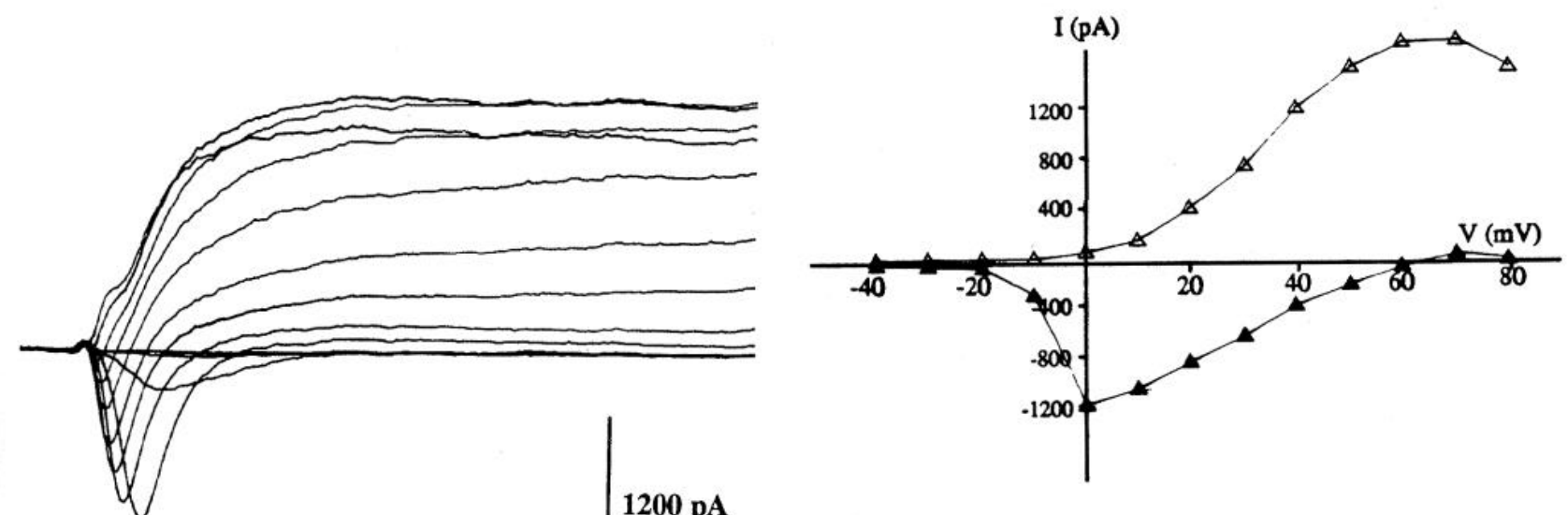

$1200 \mathrm{pA}$

$5 \mathrm{msec}$

Figure 4. Voltage-dependent currents and ultrastructural aspects of an isolated Merkel-like basal cell. $a$ is an electron micrograph of a Merkellike cell fixed immediately after patch-clamp recording. The plasma membrane has some small blebs but is relatively smooth. The cytoplasm is more electron lucent than the Merkel-like cell in the intact taste bud (compare Fig. 3a), with swollen mitochondria and disrupted tonofilaments. However, characteristic dense-cored vesicles (arrowhead) are still prominent $(b)$. Note that no spines are discernible in this section. $c$ shows the voltage-dependent currents recorded from the above cell $\left(V_{h}=-80 \mathrm{mv}\right.$; pulsed in $10 \mathrm{mV}$ steps from -40 to $\left.+80 \mathrm{mV}\right)$. The rapidly inactivating inward $\mathrm{Na}^{+}$currents were followed by sustained outward $\mathrm{K}^{+}$currents. The current/voltage relationship is plotted in $d$. The solid triangles represent the peak of the inward current at each voltage step, while the open triangles represent the peak of the outward current at each voltage step. 
Table 1. A comparison of the electrophysiological properties of presumptive stem cells and Merkel-like basal cells from Necturus taste buds

\begin{tabular}{|c|c|c|c|c|c|c|c|}
\hline \multirow[b]{3}{*}{ Cell type } & \multirow[b]{3}{*}{$\mathrm{pF}$} & \multicolumn{4}{|c|}{ Inward currents (peak) } & \multirow{2}{*}{\multicolumn{2}{|c|}{$\frac{\text { Outward current }}{\mathrm{K}^{+}}$}} \\
\hline & & \multicolumn{2}{|c|}{$\mathrm{Na}^{+}$} & \multicolumn{2}{|l|}{$\mathrm{Ba}^{2+}\left(\mathrm{Ca}^{2+}\right)$} & & \\
\hline & & Total (pA) & $\begin{array}{l}\text { Normalized } \\
(\mathrm{pA} / \mathrm{pF})\end{array}$ & Total (pA) & $\begin{array}{l}\text { Normalized } \\
(\mathrm{pA} / \mathrm{pF})\end{array}$ & Total (pA) & $\begin{array}{l}\text { Normalized } \\
(\mathrm{pA} / \mathrm{pF})\end{array}$ \\
\hline $\begin{array}{l}\text { Presumptive stem } \\
\text { basal cells }\end{array}$ & $\begin{array}{l}29.4 \pm 1.6 \\
(n=19)\end{array}$ & $\begin{array}{c}0 \\
(n=19)\end{array}$ & $\begin{array}{l}0 \\
(n=19)\end{array}$ & $\begin{array}{c}0 \\
(n=6)\end{array}$ & $\begin{array}{l}0 \\
(n=6)\end{array}$ & $\begin{array}{l}1695 \pm 501 \\
(n=19)\end{array}$ & $\begin{array}{l}71 \pm 22 \\
(n=19)\end{array}$ \\
\hline Merkel-like basal cells & $\begin{array}{l}22.3 \pm 0.6 \\
(n=22)\end{array}$ & $\begin{array}{l}983 \pm 158 \\
(n=20)\end{array}$ & $\begin{array}{l}44.7 \pm 7.1 \\
(n=20)\end{array}$ & $\begin{array}{l}314 \pm 30 \\
(n=6)\end{array}$ & $\begin{array}{l}14.7 \pm 1.3 \\
(n=6)\end{array}$ & $\begin{array}{l}2279 \pm 244 \\
(n=16)\end{array}$ & $\begin{array}{l}103 \pm 12 \\
(n=16)\end{array}$ \\
\hline
\end{tabular}

Plotted are the means \pm SEM of the peak value from a series of pulses (in $10 \mathrm{mV}$ steps) from -40 to $+80 \mathrm{mV}$. The potassium current was measured at $+80 \mathrm{mV}$.

basal cells. This current was partly blocked by $10 \mathrm{mM}$ TEA in the bath or completely blocked with $\mathrm{Cs}^{+}$in the patch pipette. These data indicate that the outward current was predominantly a $\mathrm{K}^{+}$current. A portion of the outward current may have included a contribution from $\mathrm{Ca}$-dependent $\mathrm{K}^{+}$conductances since the $I / V$ plot (Fig. $4 d$ ) displayed what might be the beginning of an $\mathrm{N}$-shaped curve that is characteristic of $\mathrm{Ca}^{2+}$-dependent $\mathrm{K}^{+}$ currents in other cell types (Adams et al., 1982; Galvan and Sedlmeir, 1984). Furthermore, Ca-dependent $\mathrm{K}^{+}$currents have been observed in mudpuppy taste receptor cells (Kinnamon and Roper, 1987). With $\mathrm{Cs}^{+}$in the patch pipette to eliminate $\mathrm{K}^{+}$ currents, two different types of inward current could be observed, a transient and a sustained inward current (Fig. $5 c, d$ ). By blocking the transient inward $\mathrm{Na}^{+}$current with TTX and replacing $\mathrm{Ca}^{2+}$ in the bath with $\mathrm{Ba}^{2+}$ (to eliminate $\mathrm{Ca}^{2+}$-dependent conductances and to enhance any inward current through $\mathrm{Ca}^{2+}$ channels) a slowly inactivating inward current could be isolated (Fig. 5e). The inward divalent cation current activated near $-20 \mathrm{mV}$ and reached a peak at $0 \mathrm{mV}$ (Fig. $5 f$ ). All of the Merkel-like basal cells examined for the presence of sustained inward current ( $n=6)$ had voltage-dependent inward $\mathrm{Ca}^{2+}$ currents. On average, Merkel-like cells were smaller than the stem basal cells with a mean capacitance $( \pm$ SEM) of $22.30 \pm 0.6 \mathrm{pF}$.

All of the Merkel-like basal cells identified with electron microscopy $(N=16)$ or with 5 -HT immunocytochemistry $(N=$ 6) had voltage-activated inward $\mathrm{Na}^{+}$currents, saturating outward $\mathrm{K}^{+}$currents, and voltage-activated $\mathrm{Ca}^{2+}$ currents. In contrast, all presumptive stem cells $(N=19)$ only showed voltageactivated outward $\mathrm{K}^{+}$currents. Table 1 summarizes these data.

\section{Discussion}

This report correlates the structure and function of isolated taste cells and provides direct evidence that there are two distinct types of basal cells in Necturus taste buds-presumptive stem cells and Merkel-like basal cells. The cytoplasm of presumptive stem cells had no distinctive organelles but included numerous mitochondria, Golgi, and disrupted tonofilaments. Morphologically, this cell type was indistinguishable from cells identified as stem cells in the intact taste bud, using uptake of tritiated thymidine as a marker. These cells had voltage-dependent outward currents only. Merkel-like basal cells were somewhat smaller than presumptive stem cells, as determined by cell capacitance measurements. In contrast to presumptive stem cells, Merkellike basal cells had two distinct morphological features: spines extending from the cell membrane and numerous dense-cored vesicles in the cytoplasm. Although the spines tended to be resorbed by the cell after isolation, the characteristic dense-cored vesicles remained after whole-cell recording and allowed one to identify Merkel-like basal cells unambiguously. Furthermore, serotonin (5-HT) immunocytochemistry was used to corroborate independently the identification of isolated Merkel-like basal cells. With voltage clamp, three separate voltage-activated currents were observed in the isolated Merkel-like cells: a transient, TTX-sensitive inward $\mathrm{Na}^{+}$current; a saturating, outward $\mathrm{K}^{+}$current; and a slowly inactivating inward $\mathrm{Ca}^{2+}$ current.

These data complement and extend the findings of Bigiani and Roper (1993), who also found that there were two physiologically distinctive populations of basal cells in intact taste buds in thin slices of lingual tissue from Necturus. Bigiani and Roper (1993) reported that there was one class of basal cell that possessed only outward $\mathrm{K}^{+}$currents. Another class of basal cell possessed inward $\mathrm{Na}^{+}$and $\mathrm{Ca}^{2+}$ currents and outward, noninactivating $\mathrm{K}^{+}$currents. Additionally, Bigiani and Roper (1993) observed that the $\mathrm{K}^{+}$currents of the two basal cell classes differed: the current in the first class showed some inactivation during a $300 \mathrm{msec}$ pulse whereas those in the other class did not. The specific cell types that were associated with these different physiological properties were not identified in that study. In the present study, the duration of the voltage pulse was too short to observe $\mathrm{K}^{+}$current inactivation. However, the two classes of basal cells identified by Bigiani and Roper (1993) in intact taste buds are consistent with them being presumptive stem cells and Merkel-like basal cells, as identified in the present study on isolated taste cells. Thus, the findings of Bigiani and Roper (1993) confirm that the differences between stem and Merkel-like cells reported here were not caused by the isolation procedures and confirm our interpretation that these are real differences that exist in situ.

\section{Presumptive stem cells}

The sequence of expression of voltage-dependent currents during development appears to be tissue specific. Developmental studies on amphibian Rohon-Beard neurons have shown that voltage-dependent currents are not expressed until a few hours after terminal mitosis (Spitzer and Baccaglini, 1976). Voltagedependent $\mathrm{Ca}^{2+}$ currents appear first, followed by a delayedrectifier $\mathrm{K}^{+}$current and then voltage-dependent $\mathrm{Na}^{+}$currents (Baccaglini and Spitzer, 1977). Conversely, outward currents appear before (or at the same time) as the inward currents in chick muscle fibers (Kano, 1975) and neural plate cells of $\mathrm{Am}$ bystoma (Warner, 1973). In Xenopus and chick embryonic neurons, all voltage-dependent currents are present when the neurons can first be reliably identified and increase in magnitude with development (O'Dowd et al., 1988; Dourado and Dryer, 1992). The most striking change in voltage-dependent currents of Xenopus spinal neurons during development occurs in the 

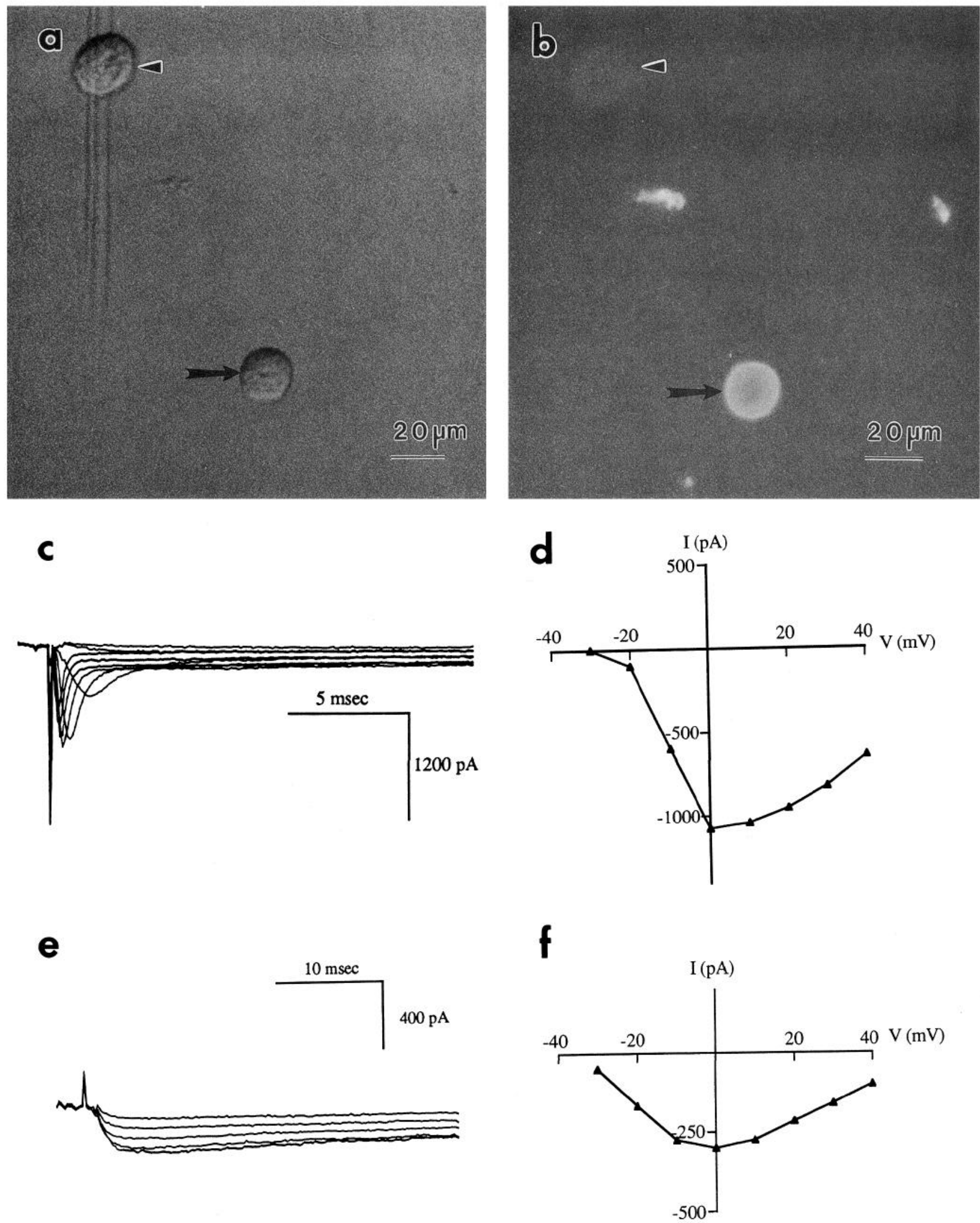

Figure 5. Immunocytochemistry and voltage-dependent currents of an isolated Merkel-like basal cell. $a$ is a light microscope micrograph of two basal cells fixed after recording from the smaller cell (arrow). $b$ shows the same cells as in $a$ but viewed with epifluorescence after labeling with anti-serotonin antiserum. The smaller cell (arrow) is immunoreactive for 5-HT, indicative that the cell is a Merkel-like basal cell. Notice that another, somewhat larger cell (arrowhead) is also visible in $a$ and $b$ and it was not immunoreactive for 5-HT (arrowhead) in $b$. By blocking $\mathrm{K}^{+}$ currents with $\mathrm{Cs}^{+}$in the patch pipette, two components of inward current were revealed in this cell $(c)$. The peak of the inward currents is shown 
voltage-dependent $\mathrm{K}^{+}$current. $\mathrm{K}^{+}$current increases threefold and activates almost twice as fast in adult versus embryonic neurons (O'Dowd et al., 1988). These features of $\mathrm{K}^{+}$current are similar to what we observed in the presumptive stem cells from Necturus taste buds compared to mature taste cclls. That is, in the stem cells, the outward current was slowly activating and relatively small compared to that observed in differentiated taste cells (i.e., Merkel-like basal cells; Table 1, Figs. $2 d, 4 c$ ). Voltage-dependent $\mathrm{Na}^{+}$and $\mathrm{Ca}^{2+}$ currents were not observed in presumptive stem cells from Necturus taste buds, although most mature taste receptor cells have such currents (Kinnamon and Roper, 1988b; Bigiani and Roper, 1993). It has been speculated that these inward currents are expressed as a developing taste cell reaches the taste pore and its epithelial-like polarity is established (Mackay-Sim et al., 1991). A consequence of the lack of voltage-dependent $\mathrm{Na}^{+}$or $\mathrm{Ca}^{2+}$ currents in presumptive stem cells is that these cells would not be expected to be electrically excitable and thus would not generate action potentials.

\section{Merkel-like basal cells}

Merkel-like basal cells are arranged in a ring around the perimeter at the base of the taste bud (Delay et al., 1993b; Kim et al., 1993). With actin-filled spines projecting from the cell surface and numerous dense-cored vesicles in the cytoplasm, Merkellike basal cells are a well-differentiated cell type. These cells do not possess any apical processes that extend to the taste pore. Thus, they cannot be directly involved in the initial transduction event (i.e., they cannot interact directly with chemical stimuli). However, they are involved in over $60 \%$ of the synapses observed between cells in Necturus taste buds (Delay and Roper, 1988). Merkel-like basal cells form morphological synapses both with innervating nerve fibers and with taste receptor cells. Some of the synapses on Merkel-like basal cells seem to be bidirectional, with synaptic vesicles clustered on both sides of the synaptic thickening (Delay and Roper, 1988).

The presence of voltage-activated $\mathrm{Na}^{+}, \mathrm{Ca}^{2+}$, and $\mathrm{K}^{+}$currents in Merkel-like basal cells suggests that these cells are electrically excitable. They should be capable of firing action potentials, and indeed, intracellular recordings from basal cells have revealed possible regenerative activity (Ewald and Roper, 1994). Furthermore, the presence of voltage-activated calcium current may indicate that Merkel-like basal cells release neurotransmitter in a Ca-dependent manner. Merkel-like basal cells contain 5-HT, have a rapid uptake system for this monoamine, and release 5-HT when depolarized (Welton and Roper, 1992). In addition, recent work in our laboratory has shown that 5-HT has several effects on receptor taste cells. For example, Delay et al. (1993a) have shown that low concentrations of 5-HT $(1-100 \mu \mathrm{M})$ modulates voltage-activated $\mathrm{Ca}^{2+}$ current in receptor taste cells. Furthermore, Ewald and Roper (1994) have demonstrated that 5-HT increases the input resistance in taste cells and enhances the cell's response to chemical stimulation (cf. Roper, 1993). Thus, Mcrkcl-likc basal cclls, which are the only cells within the taste bud that contain 5-HT, appear to function as a neuromodulator of receptor cell properties.
An alternative view of Merkel-like basal cell function was recently summarized by Toyoshima (1994). Merkel-like basal cells were postulated to release a trophic agent responsible for guiding the development and differentiation of taste buds. This interpretation is not necessarily in conflict with its proposed role as an interneuron or neuromodulator (see above) since 5-HT, which is found in Merkel-like cells, can serve as both a neurotransmitter/neuromodulator and as a neurotrophic agent (e.g., Goldberg and Kater, 1989; Goldberg et al., 1992). A somewhat related role, namely, that of a paraneuron that releases a local hormone affecting the surrounding taste cells, has been proposed for Merkel-like basal cells by Toyoshima et al. (1984) and Fujita (1991).

Merkel-like taste basal cells have been compared to cutaneous Merkel cells on the basis of several ultrastructural characteristics these cells possess in common. Both cell types have spines and dense-cored vesicles. The two cell types share a common position in epithelial tissue, namely, their similar situation on the basal lamina. Both cell types contain 5-HT, neuron-specific enolase, and various neuropeptides (Alvarez et al., 1988; Gauweiler et al., 1988; Hartschuh and Weihe, 1988; Garcia-Caballero et al., 1989; Welton et al., 1992). In addition, both cell types form synapses with innervating nerve fibers and some of the synapses appear to be reciprocal (Reutter, 1971, 1978, 1986; Parducz et al., 1977; Delay and Roper, 1988). Further, taste buds are believed to have mechanoreceptive function in addition to their established chemosensitivity (Goossens and Vandenberghe, 1974; During and Andres, 1976; Toyoshima et al., 1984) and it has seemed plausible to impute Merkel-like basal cells as the mechanosensory modality. However, some investigators have argued that these structural similarities are not enough to equate the two cell types (Munger and Ide, 1988; Whitear, 1989; Munger, 1993). Recently, Yamashita et al. (1992) isolated cutaneous Merkel cells from the footpad epidermis of rats and recorded from Merkel cells using the whole-cell configuration of the patchclamp technique. They showed that cutaneous Merkel cells had voltage-activated $\mathrm{K}^{+}$and $\mathrm{Ca}^{2+}$ currents. The $\mathrm{K}^{+}$current is different in cutaneous Merkel cells as compared to Merkel-like basal cells in taste buds. The outward $\mathrm{K}^{+}$current in cutaneous Merkel cells was composed of a sustained and a transient component and did not saturate. In Merkel-like basal taste cells, the $\mathrm{K}^{+}$current was a sustained, saturating current. Both cell types exhibited a relatively sustained inward $\mathrm{Ca}^{2+}$ current that is thought to be involved in neurotransmitter release. Thus, cutaneous Merkel cells and Merkel-like basal taste cells could release neurotransmitter in a $\mathrm{Ca}^{2+}$-dependent manner. However, unlike the findings presented in the present study, Yamashita et al. (1992) did not find voltage-dependent, TTXsensitive $\mathrm{Na}^{+}$currents in cutaneous Merkel cells. It is possible that the quinacrine, used to identify isolated Merkel cells by Yamashita et al. (1992), abolished the voltage-dependent $\mathrm{Na}^{+}$ current since we have observed that effect on isolated taste cells (S. C. Kinnamon, S. D. Roper, and R. J. Delay, unpublished observations). However, Yamashita et al. (1992) were aware of this problem and did not believe that it had occurred. It is

in the $I / V$ plot under these conditions $(d)$. When $1 \mu \mathrm{M}$ TTX and $10 \mathrm{~mm}$ TEA are included in the bath solution, a slowly inactivating inward current is revealed $(e)$. This current is blocked by $\mathrm{Cd}^{2+}$ and can be carried by $\mathrm{Ba}^{2+}$, both of which are indicative of $\mathrm{Ca}^{2+}$ currents. $f$ is a plot of the current/ voltage relationship of peak of the $\mathrm{Ca}^{2+}$ currents (shown in $e$ ) at each voltage step. In $e$ and $f$ the $\mathrm{Ca}^{2+}$ in the bath was replaced with $20 \mathrm{mM} \mathrm{Ba}^{2+}$ to enhance currents carried through the divalent cation conductance. 
equally plausible that Merkel-like basal cells from Necturus taste buds have a TTX-sensitive $\mathrm{Na}^{+}$current that is not present in rat cutaneous Merkel cells.

Instead of acting as the mechanoreceptive transducer, cutaneous Merkel cells may modulate the sensitivity of inncrvating mechanosensitive nerve fibers (Diamond et al., 1988) or act as neurotrophic cells that attract growing sensory nerve fibers (Vos et al., 1991). If these interpretations of cutaneous Merkel cell function are true, they would be in agreement with the emerging views on Merkel-like basal taste cells. Namely, both cell types would represent neuromodulator elements for adjacent primary sensory receptive units, and both cells would also exert neurotrophic influences on the development of the primary sensory receptors. These functions of cutaneous Merkel cells and Merkel-like basal taste cells-neuromodulation and neurotrophism-are mediated by 5-HT and/or neuropeptides found in common between these two cell types.

\section{References}

Adams PR, Brown DA, Constanti A (1982) M-currents and other potassium currents in bullfrog sympathetic neurones. I Physiol (Lond) 330:537-572.

Alvarez FJ, Cervantes C, Villalba R, Blasco I, Polak JM, Rodrigo J (1988) Immunocytochemical analysis of calcitonin gene related peptide and vasoactive intestinal polypeptide in cat Merkel cells and cutaneous free nerve endings: light and electron microscopic study. Cell Tissue Res 254:429-437.

Avenet P, Lindemann B (1987) Patch-clamp study of isolated taste receptor cells of the frog. J Membr Biol 97:223-240.

Avenet P, Lindemann B (1991) Non-invasive recording of receptor cell action potentials and sustained currents from single taste buds maintained in the tongue: the response to mucosal $\mathrm{NaCl}$ and amiloride. J Membr Biol 124:33-41.

Baccaglini PI, Spitzer NC (1977) Developmental changes in the inward current of the action potential in Rohon-Beard neurones. J Physiol (Lond) 271:93-117.

Behe P, DeSimone JA, Avenet P, Lindeman B (1990) Membrane currents in taste cells of the rat fungiform papilla. Evidence for two types of Ca currents and inhibition of $\mathrm{K}$ currents by saccharin. J Gen Physiol 96:1061-1084.

Beidler LM, Smallman RL (1965) Renewal of cells within taste buds. J Cell Biol 27:263-272.

Bigiani AR, Roper SD (1991) Mediation of responses to calcium in taste cells by modulation of a potassium conductance. Science 252 : 126-128.

Bigiani AR, Roper SD (1993) Identification of electrophysiologically distinct cell subpopulations in Necturus taste buds. J Gen Physiol 102: 143-170.

Delay RJ, Roper SD (1988) Ultrastructure of taste cells and synapses in the mudpuppy Necturus maculosus. J Comp Neurol 277:268-280.

Delay RJ, Roper SD (1989) Cell lineage in the mudpuppy, Necturus maculosus. Chem Senses 14:694.

Delay RJ, Kinnamon JC, Roper SD (1986) Ultrastructure of mouse vallate taste buds: II. Cell types and cell lineage. J Comp Neurol 253: 242-252.

Delay RJ, Kinnamon SC, Roper SD (1993a) Serotonin modulates voltage-activated calcium currents in Necturus taste receptor cells. Biophys J 64:A390.

Delay RJ, Taylor R, Roper SD (1993b) Merkel-like basal cells in Necturus taste buds contain serotonin. J Comp Neurol 335:606-613.

Diamond J, Mills LR, Mearow KM (1988) Evidence that the Merkel cell is not the transducer in the mechanosensory Merkel cell-neurite complex. In: Progress in brain research, pp 51-56. New York: Elsevier.

Dourado M, Dryer SE (1992) Changes in the electrical properties of chick ciliary ganglion ncurones during cmbryonic development. J Physiol (Lond) 449:411-428.

During MV, Andres KH (1976) The ultrastructure of taste and touch receptors of the frog's taste organ. Cell Tissue Res 165:185-198.

Ewald DA, Roper SD (1992) Basal cells modulate receptor cell func- tion in Necturus taste buds by a serotonergic mechanism. Soc Neurosci Abstr 18:596.

Ewald DA, Roper SD (1994) Bidirectional synaptic transmission in Necturus taste buds. J Neurosci 14:3791-3804.

Farbman AI (1965) Fine structure of the taste bud. J Ultrastruct Res 12:328-350.

Farbman AI (1980) Renewal of taste bud cells in rat circumvallate papillae. Cell Tissue Kinet 13:349-357.

Farbman Al, Yonkers JD (1971) Fine structure of the taste bud in the mudpuppy, Necturus maculosus. Am J Anat 131:353-370.

Fujita T (1991) Taste cells in the gut and on the tongue, their common paraneuronal features. Physiol Behav 49:883-885.

Galvan M, Sedlmeir C (1984) Outward currents in voltage-clamped rat sympathetic neurons. J Physiol (Lond) 356:115-133.

Garcia-Caballero T, Gallego R, Rosen E, Basanti D, Morel G (1989) Localization of serotonin-like immunoreactivity in the Merkel cells of pig snout skin. Anat Rec 225:267-271.

Gauweiler B, Weihe E, Hartschuh W, Yanaihara N (1988) Presence and coexistence of chrogranin $A$ and multiple neuropeptides in Merkel cells of mammalian oral mucosa. Neurosci Lett 89:121-126.

Gilbertson TA, Avenet P, Kinnamon SC, Roper SD (1992) Proton currents through amiloride-sensitive $\mathrm{Na}$ channels in hamster taste cells. Role in acid transduction. J Gen Physiol 100:803-824.

Goldberg JI, Kater SB (1989) Expression and function of the neurotransmitter serotonin during development of the Helisoma nervous system. Dev Biol 131:483-495.

Goldberg JI, Mills LR, Kater SB (1992) Effects of serotonin on intracellular calcium in embryonic and adult Helisoma neurons. Int $J$ Dev Neurosci 10:255-264.

Goossens N, Vandenberghe MP (1974) The basal cells in the papillae fungiformes of the tongue of the common frog, Rana temporaria $\mathrm{L}$. Arch Histol Jpn 36:173-179.

Hamill OP, Marty A, Neher E, Sakmann B, Sigworth FJ (1981) Improved patch-clamp techniques for high-resolution current recording from cell and cell-free membrane patches. Pfluegers Arch 391:85100.

Hartschuh W, Weihe E (1988) Multiple messenger candidates and marker substances in the mammalian Merkel cell-axon complex: a light and electron microscopic immunohistochemical study. Prog Brain Res 74:181-187.

Hirata $Y$ (1966) Fine structure of the terminal buds on the barbels of some fishes. Arch Histol Jpn 26:507-523.

Jakubowski M (1983) New details of the ultrastructure (TEM, SEM) of taste buds in fishes. Z Mikrosk Anat Forsch 97:849-862.

Kano M (1975) Development of excitability in cmbryonic chick skeletal muscle cell. J Cell Physiol 86:503-510.

Kashiwayanagi M, Miyake M, Kurihara K (1983) Voltage-dependent $\mathrm{Ca}^{2+}$ channel and $\mathrm{Na}^{+}$channel in frog taste cells. Am J Physiol 244: C82-C88.

Kim DJ, Delay RJ, Roper SD (1993) Merkel-like basal cells in amphibian taste buds are homologous with type III cells in mammalian taste buds. Soc Neurosci Abstr 19:1428.

Kinnamon SC (1988) Taste transduction: a diversity of mechanisms. Trends Neurosci 11:491-496.

Kinnamon SC, Roper SD (1987) Passive and active membrane properties of mudpuppy taste receptor cells. J Physiol (Lond) 383:601614.

Kinnamon SC, Roper SD (1988a) Evidence for a role of voltagesensitive apical $\mathrm{K}^{+}$channels in sour and salt taste transduction. Chem Senses 13:115-21.

Kinnamon SC, Roper SD (1988b) Membrane properties of isolated mudpuppy taste cells. J Gen Physiol 91:351-371.

Kinnamon SC, Cummings TA, Roper SD (1988) Isolation of single taste cells from lingual epithelium. Chem Senses 13:355-366.

Kinnamon SC, Cummings TA, Roper SD, Beam KG (1989) Calcium currents in isolated taste receptor cells of the mudpuppy. Ann NY Acad Sci 560:112-115.

Korte GE (1980) Ultrastructure of the taste buds of the red-eared turtle, Chrysemys elegans. J Morphol 163:231-252.

Lebond CP, Cheng H (1976) Identification of stem cells in the small intestine of the mouse. In: Stem cells of renewing cell populations (Cairnie AB, Lala PK, Osmond DG, eds), pp 7-32. New York: Academic.

Mackay-Sim A, Delay RJ, Roper SD (1991) Voltage-dependent cur- 
rents in developing and mature taste cells in mudpuppy (Necturus maculosus). Soc Neurosci Abstr 17:230.

Munger B (1993) The general somatic afferent terminals in oral mucosae. In: Mechanisms of taste transduction (Simon S, Roper S, eds), pp 83-101. Boca Raton, FL: CRC.

Munger BL, Ide C (1988) The structure and function of cutaneous sensory receptors. Arch Histol Cytol 51:1-34.

Murray RG (1973) The ultrastructure of taste buds. In: The ultrastructure of sensory organs (Friedemann X, ed), pp 1-81. Amsterdam: Holland.

Murray RG, Murray A (1971) Relations and possible significance of taste bud cells. Contrib Sens Physiol 5:47-95.

Oakley B (1991) Neuronal-epithelial interaction in mammalian gustatory epithelium. In: Regeneration of vertebrate sensory receptor cells (Whelan J, ed), pp 277-287. London: Ciba Foundation.

O'Dowd D, Ribera AB, Spitzer NC (1988) Development of voltagedependent calcium, sodium and potassium currents in Xenopus spinal neurons. J Neurosci 8:792-805.

Parducz A, Leslie RA, Cooper E, Turner CJ, Diamond J (1977) he Merkel cells and the rapidly adapting mechanoreceptors of the salamander skin. Neuroscience 2:511-521.

Raderman-Little R (1979) The effect of temperature on the turnover of taste bud cells in catfish. Cell Tissue Kinet 12:269-280.

Reutter K (1971) Die Geschmacksknospen des Zwergwelses Amiurus nebulosus (Lesueur). Morphol Histochem Untersuch Z Zellforsch 120: 280-303.

Reutter K (1978) Taste organ in the bullhead (Teleostei). Adv Anat Embryol Cell Biol 55:1-98.

Reutter K (1986) Chemoreceptors. In: Biology of the integument, Vol 2, Vertebrates (Bereiter-Hahn J, Matoltsy AG, Richards KS, eds), pp 586-604. Berlin: Springer.

Reutter K, Witt M (1993) Morphology of vertebrate taste organs and their nerve supply. In: Mechanisms of taste transduction (Simon SA, Roper SD, eds), pp 29-82. Boca Raton, FL: CRC.

Roper SD (1983) Regenerative impulses in taste cells. Science 220: 1311-1312.
Roper SD (1992) The microphysiology of peripheral taste organs. J Neurosci 12:1127-1134.

Roper SD (1993) Synaptic interactions in taste buds. In: Mechanisms of taste transduction (Simon SA, Roper SD, eds), pp 275-294. Boca Raton, FL: CRC

Spitzer NC, Baccaglini PI (1976) Development of the action potential in embryo amphibian neurons in vivo. Brain Res 107:610-616.

Sugimoto K, Teeter KH (1990) Voltage-dependent ionic currents in taste receptor cells of the tiger salamander. J Gen Physiol 96:809834.

Toyoshima K (1994) Merkel cells are responsible for initiation of taste bud morphogenesis in some vertebrates. In: International Society for Olfaction and Taste, XI, in press.

Toyoshima K, Nada O, Shimamura A (1984) Fine structure of monoamine-containing basal cells in the taste buds on the barbels of three species of teleosts. Cell Tissue Res 235:479-484.

Vos P, Stark F, Pittman RN (1991) Merkel cells in vitro: production of nerve growth factor and selective interactions with sensory neurons. Dev Biol 144:281-300.

Warner AE (1973) The electrical properties of the ectoderm in the amphibian embryo during induction and early development of the nervous system. J Physiol (Lond) 235:267-286.

Welton J, Roper SD (1992) In vitro uptake of tritiated serotonin in taste buds of the mudpuppy: Necturus maculosus. Chem Senses 17: 719.

Welton J, Taylor R, Porter AJ, Roper SD (1992) Immunocytochemical survey of putative neurotransmitters in taste buds from Necturus Maculosus. J Comp Neurol 324:509-521.

Whitear M (1989) Merkel cells in lower vertebrates. Arch Histol Cytol [Suppl] 52:415-422.

Yamashita Y, Akaike N, Wakamori M, Ikeda I, Ogawa H (1992) Voltage-dependent currents in isolated single Merkel cells of rats. J Physiol (Lond) 450:143-162. 